\title{
Hormigón ligero autocompactante con fibras para rehabilitación de forjados
}

\section{Lightweight self-compacting concrete reinforced with fibres for slab rehabilitation}

\author{
N. S. Klein ${ }^{(*)}$, A. de la Fuente(*), A. Aguado(*), D. Masó(**)
}

Recepción/Received: 16-X-09

Aceptación/Accepted: 2-II-10

Publicado online/Online publishing: 20-VI-11

RESUMEN

Los forjados de ciertos edificios del ensanche de Barcelona, formados por viguetas unidireccionales con un revoltón de cerámica entre ellas y un relleno posterior (material cerámico y residuos de construcción), suelen presentar problemas de movimientos y despegues de las baldosas situadas en la parte superior, con el consiguiente riesgo para el usuario, aparte de los problemas de durabilidad asociados. Para rehabilitar esas estructuras se ha diseñado un hormigón ligero autocompactante con fibras (HLACF), como relleno de modo que mejore la rigidez a la estructura.

El artículo presenta el análisis estructural de una solución tipo así como los resultados de una campaña experimental realizada. Como resultado se obtiene un hormigón de densidad de $1.665 \mathrm{~kg} / \mathrm{m}^{3}$, escurrimiento de $605 \mathrm{~mm}$ y resistencia a compresión de $22,3 \mathrm{MPa}$, a los 28 días, que cumple con los requisitos y significa superar problemas de segregación previsibles para este tipo de hormigones.

Palabras clave: aditivo cohesionante, hormigón ligero, hormigón autocompactante, fibras, rehabilitación.
SUMMARY

The slabs of some buildings in Barcelona are formed by unidirectional beams, with a ceramic arch in between, which are filled with broken pottery or construction waste. These structures often present problems such as displacement of the tiles arranged over it due to the lack of stiffness of the filling material. This supposes a risk to the user and could also cause durability problems. In order to rehabilitate it, a lightweight self-compacting concrete reinforced with fibres (HLACF) has been designed to be used as a filling material, improving the stiffness of the structure.

This paper presents a structural analysis of a standard case and the results of an experimental campaign. The concrete showed a density of $1665 \mathrm{~kg} / \mathrm{m}^{3}$, a slump flow of $605 \mathrm{~mm}$ and a compressive strength of $22.3 \mathrm{MPa}$, at 28 days. These results are in agreement with the requirements, overcoming common lightweight concrete segregation problems.

Keywords: viscosity modifier admixture, lightweight concrete, self-compacting concrete, fibres, rehabilitation.

\footnotetext{
(*) Universidad Politécnica de Cataluña (Barcelona, España).

(**) PROMSA (Barcelona, España).
} 


\section{INTRODUCCIÓN}

En los edificios de la zona del ensanche de Barcelona, diseñada por Ildelfons Cerdà, la solución estructural usualmente adoptada para los forjados fue la de viguetas unidireccionales con un revoltón de cerámica entre ellas y un relleno posterior, en muchos casos de cascotes de cerámica, de los incipientes residuos de construcción $(1,2)$, tal como se muestra en la Figura 1 . Este relleno tenía por función dar la planeidad necesaria en la parte superior del forjado y asegurar un cierto monolitismo del mismo, ya que con frecuencia no se disponía de una armadura de reparto.

\section{INTRODUCTION}

The buildings in the area which expanded from the citadel of Barcelona were designed by Ildelfons Cerdà. The common structural solution adopted for the slabs of these buildings consists of unidirectional beams, with a ceramic arch in between, as shown in Figure 1. A filling material is placed between the arch and the upper floor, which is often formed by broken pottery or construction waste $(1,2)$. The basic function of the filling material is to provide flatness at the upper side of the slab and to guarantee a monolithic structure, even though reinforcement is commonly not present over the beams.

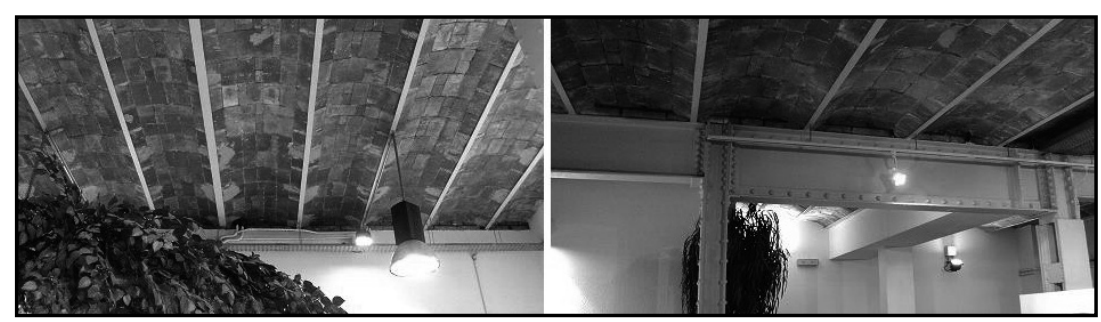

Figura 1. Vista inferior típica de los forjados estudiados.

Figure 1. Typical bottom view of the slabs studied.

En esta configuración, cuando una carga se sitúa encima de una vigueta, el reparto transversal de la carga es pequeño, fruto de la escasa rigidez transversal, lo que conduce a movimientos y despegues de las baldosas que se sitúan en la parte superior del forjado. Ello aumenta el riesgo de rotura de las mismas y de pérdida de durabilidad al entrar con mayor facilidad los agentes agresivos de los líquidos de limpieza. Además, esta movilidad de las baldosas supone riesgos de tropiezos para las personas, especialmente aquéllas de edades avanzada con movilidad reducida y visión parcial.

Cuando con el paso del tiempo o del cambio de función de estos edificios se requieren actuaciones de rehabilitación de los mismos, hay que considerar diversos factores a los que dar respuesta, entre ellos: aumentar el monolitismo, no aumentar el peso de la estructura, adecuar la puesta en obra del material de relleno a las circunstancias urbanas, lo que se traduce en un tiempo mínimo de ocupación de vía pública.

Para dar respuesta a estos condicionantes cabe pensar en un hormigón ligero autocompactante con fibras estructurales (HLACF). La característica de ligereza viene dada para no aumentar peso en la estructura y poder aumentar, si cabe los espesores; la autocompactabilidad por facilidad constructiva y reducir tiempos de puesta en obra; mientras que las fibras es para dar rigidez transversal y ciertas características mecánicas. Esta solución de rehabilitación consiste en eliminar la superestructura, que no desarrolla ninguna función resistente (baldosas y
In this configuration, when a load is placed over a beam, the transversal distribution of the load is deficient. This is a consequence of the low transversal stiffness, which creates movement and detachment of the tiles arranged over the slab. Therefore, the durability of the structure is compromised because it facilitates the entrance of aggressive agents from the cleaning products. In addition, the movement of the tiles provokes imperfections on the floor that could lead to injury of the user, especially of elderly people, who may have disabilities of movement or vision.

With the passing of time or the changing of the function of the buildings, rehabilitation is required. For the situation presented in this paper, several factors should be observed, such as: the necessity of producing monolithic structures, maintaining the structure weight or adapting the casting of the filling material to urban reality, bearing in mind the reduction of time of public highway occupation.

To address these conditions, it is proper to think about a lightweight self-compacting concrete reinforced with fibres (HLACF, from Spanish hormigón ligero autocompactante con fibras). The lightweight feature meets the need of maintaining the structure weight and even allows increasing the thickness of some elements. The selfcompactability facilitates the construction process and reduces the time of casting, and fibres provide stiffness and better mechanical characteristics. The rehabilitation solution consists of removing the supra-structure that 
relleno), manteniendo el arco de mampostería y los perfiles guía. Posteriormente se efectuaría un relleno con HLACF para finalmente restituir el pavimento.

Esta propuesta es un reto importante, ya que con esta configuración existen propiedades contrapuestas, por ejemplo, la ligereza alcanzada con áridos ligeros puede hacer que los mismos floten, esto es, se segreguen, en un hormigón autocompactante. La literatura técnica es abundante en referencias a hormigones autocompactantes ligeros o con fibras, en la que se alertan de ciertas dificultades (3), pero es muy escasa en cuanto al material propuesto. Experimentos con hormigón ligero autocompactante con fibras de acero han sido realizados (4), pero los resultados mecánicos están por debajo de las prestaciones requeridas en este caso.

El presente trabajo tiene como objetivos, por un lado, acotar el orden de magnitud de las características mecánicas requeridas para estos hormigones a nivel sección y, por otro, demostrar la viabilidad de los mismos, desde el punto de vista experimental del material. En trabajos posteriores se pondrá de manifiesto la viabilidad industrial, la cual ya se ha contrastado.

Para dar respuesta a estos objetivos, en primer lugar se hace un análisis estructural con una solución tipo, cara a definir las prestaciones estructurales requeridas, para después explicar en detalle los resultados obtenidos en la campaña experimental del material. Además, con ello se pretende mostrar una visión integrada de los problemas de ingeniería, necesaria para dar una respuesta satisfactoria a los mismos, lo que aumenta la aceptación industrial del resultado. El HLACF presentado en este artículo se ha patentado y licenciado a la empresa PROMSA (5).

\section{VERIFICACIÓN ESTRUCTURAL}

\subsection{Esquema estructural y cargas aplicadas}

Para este cálculo inicial las magnitudes que se van a tomar son algo superiores a las usuales cara a acotar órdenes de magnitud. Para ello se toma un forjado rectangular de $5 \times 10 \mathrm{~m}$ apoyado en los extremos, en que la dirección de las viguetas es paralela al lado corto, considerando un entrevigado de $1 \mathrm{~m}$, tal como se muestra en la Figura 2. En ella, para la comprobación de los estados límite, se han tomado cuatro secciones de control (con la letra $\mathrm{S}$ ), a la que se adjunta un número que indica el canto de la sección en $\mathrm{cm}$. does not develop any mechanical function (tiles and filling material), while maintaining the ceramic arch and the beams. Subsequently, the filling with HLACF would be carried out. After that, the restitution of the tiles would take place.

The production of the HLACF is considered a challenge because the contrasting properties are inherent to the configuration proposed. A clear example of that is the use of lightweight aggregates, which could promote segregation with their floatation on a self-compacting mortar. Although the technical literature makes ample references to some types of SCC, like lightweight SCC or SCC with fibres, and it also contains information on the potential problems (3), there are scarce references when it comes to the proposed material. Experimentation with lightweight self-compacting concrete with steel fibres has been developed (4), but the mechanical results are insufficient when contrasted to the performance required in the present situation.

The first purpose of this paper is to determine the order of magnitude of the mechanical characteristics required by the HLACF at a sectional level. And the second one is to demonstrate the viability of this concrete from an experimental point of view. In forthcoming papers, the industrial viability will be analysed since it has already been verified.

To address these matters, a structural analysis for a standard structure is firstly developed with the objective of defining the basic requirements. Later, the results obtained in the concrete experimental campaign will be presented and analysed. The aim of the strategy is to offer an integrated vision of the engineering problems. This is important in order to solve them satisfactorily and increase the industrial acceptance of the results. The HLACF presented in this paper has been patented and licensed by the PROMSA Company (5).

\section{STRUCTURAL VERIFICATION}

\subsection{Structural scheme and applied loads}

For this initial calculation, the structure dimensions that were adopted were slightly higher than the real ones, as the main purpose was only to determine the order of magnitude of the concrete requirements. For this, a rectangular slab of $5 \times 10$ metres is considered, in which the direction of the beams is parallel to the short side of the slab, and the distance between each beam is of 1 metre, as shown in Figure 2. To verify the limit states, 4 sections were chosen (indicated with the letter $S$ ). The numbers indicate the height of the section in $\mathrm{cm}$. 


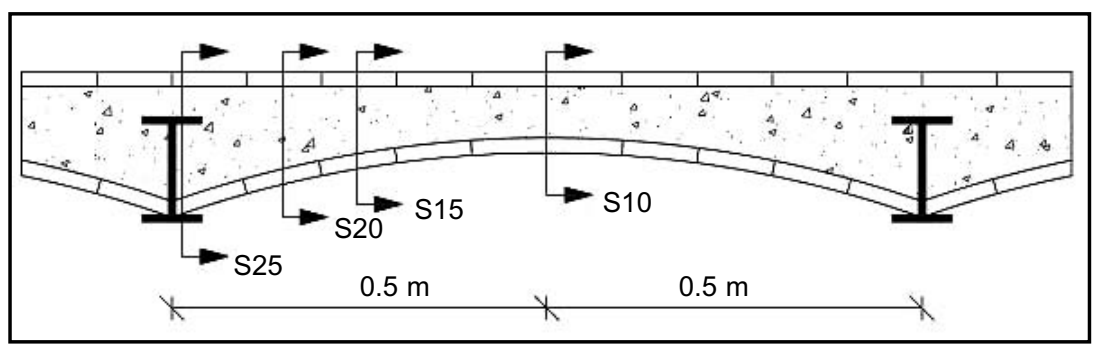

Figura 2. Secciones tomadas como representativas del comportamiento del arco. Figure 2. Sections taken as representatives of the arch behavior.

De cara al cálculo de esfuerzos, se ha considerado que el forjado está simplemente apoyado en las cuatro aristas perimetrales. Esta configuración es la que conduce a los esfuerzos de flexión de mayor magnitud en el centro de la losa y a los máximos desplazamientos. Este tratamiento numérico de las condiciones de contorno sirve para acotar órdenes de magnitud, si bien es razonablemente realista, ya que puede encontrarse que estos forjados no tienen continuidad y no se prevé la colocación de ninguna armadura pasante losa-muro que garantice una conexión y un cierto grado de rigidez. Por otra parte, se ha considerado el empotramiento de las vigas metálicas al estar éstas embebidas en los muros laterales.

Como sección resistente se considera sólo la parte compuesta por el HLACF, que, al no existir armadura en forma de barras, se comporta de la misma forma frente a esfuerzos de flexión de signo positivo y signo negativo. Si bien, se recuerda que la sección transversal se completa con un entramado inferior de cerámica (arco) y superior de baldosas (piso), con lo que la resistencia real es ligeramente superior. Sin embargo, este posible incremento no se tiene en cuenta por varios aspectos: la dificultad de modelar esta situación y porque su contacto y posición irregular inducen a pensar a que éstas puedan no trabajar de forma monolítica.

Para la verificación de los estados límite se han tomado como válidas las acciones y combinaciones sugeridas en SE-AE Acciones en la Edificación (6). Concretamente, se ha supuesto que se trata de estructuras con una categoría de uso tipo residencial $(A)$ y subcategoría $A 2$. Por lo tanto, teniendo en cuenta las sugerencias recogidas en este código, la carga uniforme $\mathrm{q}_{\mathrm{p}}$ toma un valor de $3 \mathrm{kN} / \mathrm{m}^{2}$ y la sobrecarga de naturaleza concentrada $\mathrm{q}_{\mathrm{c}}$ de $2 \mathrm{kN} / \mathrm{m}^{2}$. Estas acciones se combinan y mayoran adecuadamente, junto con el peso propio de la estructura y superestructura, para obtener los esfuerzos con los que se diseña el refuerzo del hormigón.

\subsection{Materiales y metodología de análisis}

El análisis realizado se apoya en la campaña experimental que se presenta posteriormente. En la misma se han
With the purpose of calculating the internal forces, it has been considered that the slab is simply supported in the four perimeter edges. This configuration leads to the highest bending moments in the centre of the slab and also to the maximum displacements. This numerical treatment of the boundary conditions is important to determine the orders of magnitude. But it is also reasonably realistic as these slabs do not present continuity and there is no reinforcement between the slab and the structural wall that might guarantee the connection or stiffness. On the other hand, the steel beams were considered embedded in the lateral wall.

The resistant section considered is only the $H L A C F$, which -in the absence of bar reinforcement- behaves in the same way in the presence of bending forces of both positive and negative sign. It is important to highlight that the transversal section is formed in the bottom side with the ceramic arch and in the top with the tiles (floor), so that the strength is slightly higher. However, this possible increase is not taken into account for a couple of reasons: due to the difficulty to model this situation and because its contact and irregular position may lead to think that all these elements don't work in a monolithic way.

To verify the limit states, the actions and combinations proposed by the SE-AE Acciones en la Edificación (6) have been taken as valid. More specifically, it has been considered that the buildings belong to the residential category type $(A)$, subcategory $A 2$. Therefore, considering the suggestions proposed in this code, the uniform load $q_{p}$ is $3 \mathrm{kN} / \mathrm{m}^{2}$ and the concentrated overload $q_{c}$ is $2 \mathrm{kN} / \mathrm{m}^{2}$. These actions are properly combined, together with the weight of the structure and the supra-structure in order to obtain the internal forces used to design the concrete reinforcement.

\subsection{Materials and analysis method}

The analysis carried out is supported by the experimental campaign presented later. During this campaign both 
utilizado tanto fibras de acero como fibras sintéticas, en ambos casos estructurales, aunque para el estudio estructural inicial que se presenta a continuación se consideran sólo las fibras sintéticas, ya que, en general, dan una respuesta residual menor frente a las tracciones que las fibras de acero. En este estudio numérico se ha considerado la fibra tipo Strux 90/40 de la que se dispone de ensayos de contrastación (7). La resistencia característica a compresión considerada para el hormigón es de 25 MPa y el peso específico medio es de $18 \mathrm{kN} / \mathrm{m}^{3}$.

La modelización del comportamiento a compresión y a tracción del HLACF se aborda mediante una curva que considera el softening del mismo (8) y la ley constitutiva propuesta por el TDF-162 Committee (9), respectivamente. En la Tabla 1 se recogen los valores de los parámetros de tensión y deformación $\left(\sigma_{\mathrm{i}} \mathrm{y} \varepsilon_{\mathrm{i}}\right.$, respectivamente) empleados en la definición de la curva constitutiva del HLACF traccionado (7). Los valores relativos a las cuantías de fibras de 2,28 y $4,55 \mathrm{~kg} / \mathrm{m}^{3}$ son reales, mientras que para el resto de cuantías de fibras se ha extrapolado linealmente. En primera aproximación, este es un planteamiento válido y justificado para fibras metálicas en cuantías moderadas (10). Esos valores se han considerado válidos para representar el comportamiento de este hormigón a nivel seccional. steel and synthetic structural fibres were used. However, for the structural analysis initially made, only synthetic fibres were considered because they generally present a tensile residual strength smaller than that of the steel fibres. In this numerical study, Strux 90/40 fibres were considered since contrasting results were available (7). The compressive strength considered was $25 \mathrm{MPa}$ and the specific weight was $18 \mathrm{kN} / \mathrm{m}^{3}$.

The modelling of the compressive and the tensile behaviour of HLACF is simulated using a curve considering the softening behaviour of concrete in compression (8) and the constitutive law suggested by the TDF-162 Committee (9), respectively. In Table 1 the parameter values of stress and strain $\left(\sigma_{i}\right.$ and $\varepsilon_{i}$ respectively) used for the definition of the constitutive curve of HLACF in tension are presented (7). The relative values and the fibres content of 2.28 and $4.55 \mathrm{~kg} / \mathrm{m}^{3}$ are real, while the other fibre contents were linearly extrapolated. As a first approximation, this approach is valid and justified for moderated amounts of steel fibres (10). These values have been considered valid for representing the behaviour of concrete at sectional level.

Tabla 1 / Table 1

Valores de los parámetros de la ecuación constitutiva ( $\sigma_{\mathrm{i}}$ y $\varepsilon_{\mathrm{i}}$ son la tensión y la deformación, respectivamente). Parameter values of the constitutive equation ( $\sigma_{i}$ and $\varepsilon_{i}$ are stress and strain, respectively).

\begin{tabular}{|c|c|c|c|c|c|c|c|}
\hline Fibras / Fibres $\left.\mathbf{( k g} / \mathbf{m}^{3}\right)$ & $\mathbf{f}_{\text {ck }}(\mathbf{M P a})$ & $\sigma_{\mathbf{1}}(\mathbf{M P a})$ & $\sigma_{\mathbf{2}}(\mathbf{M P a})$ & $\sigma_{\mathbf{3}}(\mathbf{M P a})$ & $\varepsilon_{\mathbf{1}}(\mathbf{m m} / \mathbf{m})$ & $\varepsilon_{\mathbf{2}}(\mathbf{m m} / \mathbf{m})$ & $\varepsilon_{\mathbf{3}}(\mathbf{m m} / \mathbf{m})$ \\
\hline 2.28 & 25 & 2.75 & 0.50 & 0.31 & 0.0859 & 0.186 & 25.000 \\
\hline 4.55 & 25 & 2.75 & 0.69 & 0.49 & 0.0859 & 0.186 & 25.000 \\
\hline 5.5 & 25 & 2.75 & 0.77 & 0.56 & 0.0859 & 0.186 & 25.000 \\
\hline 6.5 & 25 & 2.75 & 0.85 & 0.63 & 0.0859 & 0.186 & 25.000 \\
\hline 7.5 & 25 & 2.75 & 0.94 & 0.71 & 0.0859 & 0.186 & 25.000 \\
\hline
\end{tabular}

La estrategia de diseño del refuerzo que se ha seguido se inicia con el cálculo de los esfuerzos pésimos bajo las combinaciones derivadas de las hipótesis de cargas, y considerando la linealidad de la respuesta estructural. Para ello, se ha empleado el programa SAP2000 v.11.0 non-linear, versión a partir del cual se ha modelado la losa de forjado mediante elementos planos tipo lámina y las vigas metálicas con elementos lineales tipo viga.

Con los esfuerzos obtenidos del análisis anterior, se acude al modelo de Análisis Evolutivo de Secciones (AES) $(11,12)$ para simular el comportamiento de las cuatro secciones de control. Conocido el comportamiento global de estas secciones, se iteran con distintas cuantías de fibras hasta que todos los esfuerzos de diseño son compatibles con las dimensiones y el refuerzo de las secciones de control.
The design strategy adopted for the reinforcement was initiated with the calculation of the unfavourable internal forces under the combinations derived from the hypothesis of loads, and considering the linearity of the structural response. In order to do this, the software SAP2000 v.11.0 non-linear version was used to model the slab through 2D elements; and the metallic beams, through beam elements.

With the internal forces values obtained from previous analyses, the model Análisis Evolutivo de Secciones (AES) $(11,12)$ is used to simulate the behavior of the 4 control sections. When the global behavior of these sections is known, an iteration is carried out with several fibre contents until all the design bending moments are compatible with the dimentions and the reinforcement of the control sections. 


\subsection{Resultados y discusión}

\subsubsection{Nivel estructural}

Mediante el análisis estructural a través del método de los elementos finitos (MEF), se constata que la estructura tiene un comportamiento unidireccional predominante. Se comprueba que las flexiones $\mathrm{M}_{\mathrm{yy}}$ son despreciables en prácticamente toda la zona central de la losa, tal como se observa en la Figura 3. De hecho, las flexiones se concentran en la zona del contacto perfil-hormigón por cuestiones de compatibilidad de movimiento y efectos locales, que al mismo tiempo son las zonas donde el canto es mayor y, por lo tanto, mayor es la respuesta resistente. Con este razonamiento, se constata que el comportamiento predominante es el unidireccional en dirección $x$, tal como muestra la Figura 4, por lo que se tomará dicha dirección como la de análisis.

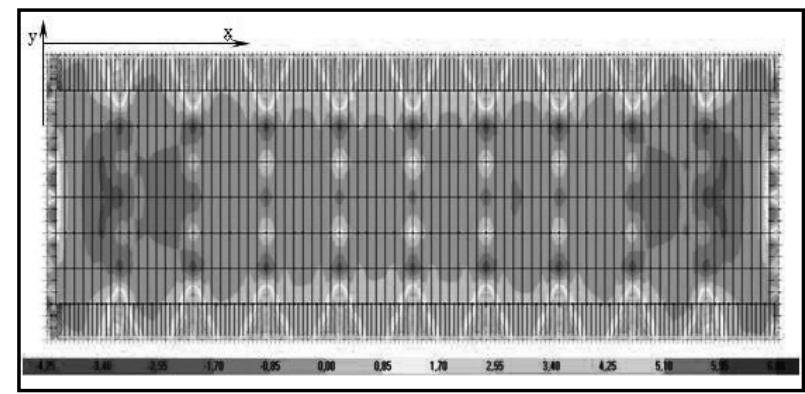

Figura 3. Esfuerzos flectores en dirección y $\left(\mathrm{M}_{\mathrm{yy}}\right)$. Figure 3. Bending moments in the $y$ direction $\left(M_{y y}\right)$.

La Tabla 2 recoge los esfuerzos de diseño $\left(M_{d}\right)$ de las secciones que se han tomado como representativas (véase Figura 2) y que se emplean para verificar el ELU de agotamiento por solicitaciones normales. Debido a la continuidad estructural en la transición perfil metálicohormigón (S25), se generan unos esfuerzos flectores negativos (compresión en la cara inferior del forjado) que decrecen hasta cambiar de signo (tracciones en la cara inferior del forjado), en las zonas de centro luz. Si bien, tal como se observa en la misma Tabla 2, los esfuerzos de flexión en las proximidades del contacto perfil-hormigón (S25) son aproximadamente diez veces superiores a los que se dan en las secciones situadas en centro luz (S10).

\subsection{Results and discussion}

\subsubsection{Structural level}

Through the structural analysis using the finite elements method (FEM), it is verified that the structure presents a predominant unidirectional behaviour. It is demonstrated that the bending moments $M_{y y}$ are negligible in practically the whole central zone of the slab, as shown in Figure 3. Indeed, the bending moments are concentrated on the area of contact between beam and concrete for reasons of compatibility of movement and local effects. At the same time, at this area, the concrete presents a higher height. For this reason, its strength response is also higher. Thus, it is verified that the predominant behaviour is unidirectional in the direction $x$, as shown in Figure 4. Therefore, the structural analysis will be carried out considering this direction.

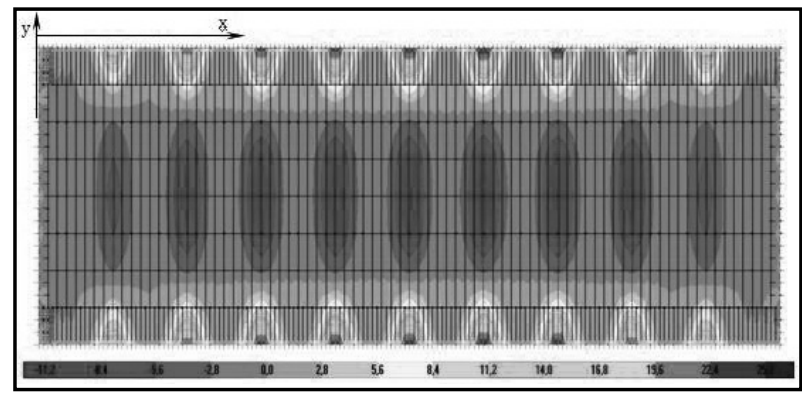

Figura 4. Esfuerzos flectores en dirección $\mathrm{x}\left(\mathrm{M}_{\mathrm{xx}}\right)$. Figure 4. Bending moments in the $x$ direction $\left(M_{x x}\right)$.

The design bending moments $\left(M_{d}\right)$ from the sections considered as representative (see Figure 2) are taken to verify the ULS. These bending moments are shown in Table 2. Due to the structural continuity in the beam concrete contact area (S25), negative bending moments are generated (compression on the bottom side of the slab), which are decreased until the sign is changed (tensile on the bottom side of the slab), in the centre zone between two beams. Indeed, the bending moments in the beam-concrete area of contact (S25) are approximately 10 times higher than the ones in the centre section (S10).

Tabla 2 / Table 2

Esfuerzos de diseño $M_{d}$ (valor absoluto) para las secciones de control (mkN/m). Design bending moments $M_{d}$ (absolute value) for the control sections $(\mathrm{m} k \mathrm{~N} / \mathrm{m})$.

\begin{tabular}{|c|c|c|c|}
\hline S25 & S20 & S15 & S10 \\
\hline 23.0 & 14.3 & 8.0 & 2.0 \\
\hline
\end{tabular}

Otro de los parámetros a controlar en este estudio es el desplazamiento máximo de la estructura. El control de esta variable, dentro de un margen razonable para este
Another parameter that should be controlled is the maximum displacement of the structure. Controlling this variable to a reasonable extent would prevent the 
tipo de estructuras, evitará los movimientos de las baldosas superiores y las consiguientes repercusiones a nivel estético y funcional. Los cálculos muestran que el desplazamiento máximo alcanzado es de $0,8 \mathrm{~mm}$ en la hipótesis más desfavorable (peso propio + sobrecarga uniforme + sobrecarga concentrada). Este valor es suficientemente pequeño para garantizar que, en la realidad, con distancias entre ejes menores a $1 \mathrm{~m}$ considerado en este caso, las baldosas no sufren movimientos relativos y se despeguen del entramado.

\subsubsection{Nivel de sección}

Con el modelo numérico AES $(11,12)$ se obtienen los momentos de rotura $M_{u}$ para distintos cantos $h$ y distintas cantidades de fibras $\rho$. En este sentido, se ha trabajado con cantos que oscilan entre 10 y $25 \mathrm{~cm}$ (cantos de las secciones representativas en la Figura 2) y cuantías de fibras dentro del rango 2,28 y $7,5 \mathrm{~kg} / \mathrm{m}^{3}$, que se han considerado técnica y económicamente atractivas. Los resultados muestran que $M_{u}$ crece de forma parabólica con $\rho$, según la expresión [1], donde el parámetro $\zeta_{1}$ depende, para el tipo de fibra y hormigón fijados, de la cantidad de fibras $(\rho)$. movement and detachment of the tiles, and the consequent repercussions at the esthetical and functional levels. The calculation shows that the maximum displacement is of $0.8 \mathrm{~mm}$ in the most unfavourable hypothesis (self weight + uniform overload + centred overload). This value is sufficiently small to guarantee that in real structures, with distances smaller than 1 metre between beams, the tiles would not suffer any displacement or detachment.

\subsubsection{Sectional level}

The numerical model AES $(11,12)$ provides failure bending moments $M_{u}$ for distinct $h$ heights and different amounts of $\rho$ fibres. The height values adopted vary from 10 to $25 \mathrm{~cm}$ (height of the control sections presented in Figure 2) and the fibre content between 2.28 and $7.5 \mathrm{~kg} / \mathrm{m}^{3}$, which were considered technically and economically viable. The results show that $M_{u}$ increases in a parabolic way with $\rho$, according to the expression [1], where $\xi_{1}$ depends on the fibre content $(\rho)$, considering a specific fibre type and concrete.

$$
M_{u}=\xi_{1} h^{2}=10^{-3}(3,53 \rho+11,04) h^{2}(m k N / m)
$$

Así pues, empleando la ecuación [1] y teniendo en cuenta las cargas de diseño de la Tabla 3, se pueden obtener las densidades de fibras mínimas para dar la respuesta estructural requerida.
Therefore, using equation [1] and considering the design loads presented in Table 3, it is possible to calculate the minimum fibre densities necessary to meet structural requirements.

Tabla 3 / Table 3

Cálculo de la cuantía mínima de fibras $\rho_{\min }$ con la ecuación [1].

Calculation of the minimum fibre content $\rho_{\min }$ using equation [1].

\begin{tabular}{|c|c|c|c|}
\hline Sección / Section & $\mathbf{h}(\mathbf{c m})$ & $\mathbf{M}_{\mathbf{d}}(\mathbf{m k N} / \mathbf{m})$ & $\rho_{\text {min }}\left(\mathbf{k g} / \mathbf{m}^{3}\right)$ \\
\hline S25 & 25 & 22.3 & 7.0 \\
\hline S20 & 20 & 14.3 & 6.8 \\
\hline S15 & 15 & 8.0 & 6.9 \\
\hline S10 & 10 & 2.0 & 2.5 \\
\hline
\end{tabular}

A raíz de los resultados recogidos en la Tabla 3, se constata que el diseño del refuerzo está gobernado por el comportamiento seccional en el contacto perfil-losa, que es donde se desarrollan los mayores esfuerzos de flexión (flexión negativa). En este sentido, la cuantía de fibras mínima $\rho_{\min }$ que debería emplearse sería de $7,0 \mathrm{~kg} / \mathrm{m}^{3}$, ya que para valores de inter-ejes menores, las flexiones serían a también menores $y$, en consecuencia, menor la cantidad de fibras necesaria para hacer frente a los esfuerzos de diseño.

Cabe recordar que este análisis inicial se ha realizado para acotar los órdenes de magnitud de las variables que
According to the obtained results shown in Table 3, it is verified that the reinforcement design is governed by the sectional behaviour in the beam-concrete contact area, where the highest bending moments are developed (negative flexion). Thus, the minimum fibre content $\rho_{\text {min }}$ that should be used is of $7.0 \mathrm{~kg} / \mathrm{m}^{3}$, because, for smaller distances between beams, the bending moments and the fibre content needed to address the respective requirements will also be lower.

It is important to highlight that this initial structural analysis was carried out in order to determine the order 
intervienen en el diseño de estos elementos y del hormigón a diseñar. En realidad, se han tomado valores mayores que los usuales en la práctica. Asimismo, de caras a verificar la viabilidad de este tipo de material, las prestaciones consideradas han sido, para estado fresco un diámetro de escurrimiento de $600 \pm 50 \mathrm{~mm} \mathrm{y}$, en estado endurecido una densidad inferior a $1.700 \mathrm{~kg} / \mathrm{m}^{3}$ y una resistencia a compresión mínima de $20 \mathrm{MPa}$ a los 28 días.

\section{PROGRAMA EXPERIMENTAL}

Una vez acotado el orden de magnitud de las prestaciones requeridas para este tipo de material, se ha planteado una campaña experimental, para analizar la viabilidad de la propuesta del HLACF.

\subsection{Materiales y dosificación}

Los materiales seleccionados para la campaña experimental son:

- Como áridos gruesos: áridos ligeros de arcilla expandida de dos plantas de la misma marca: uno de ellos tiene forma esférica y el otro una forma más ovalada. Además, se han utilizado áridos ligeros con dos rangos granulométricos, $3-10 \mathrm{~mm}$ y $6-16 \mathrm{~mm}$, los cuales corresponden a densidades de (550 \pm 50 ) $\mathrm{kg} / \mathrm{m}^{3}$ y $(325 \pm 50) \mathrm{kg} / \mathrm{m}^{3}$, respectivamente. Estos áridos se han adicionado a las mezclas en la condición seca, sin saturación previa.

- La arena 0-4 mm y gravilla 4-10 mm se han empleado como áridos naturales calizos de machaqueo. Asimismo, se ha utilizado un fíller calcáreo como adición mineral, cara a mejorar la trabajabilidad y la función autocompactante.

- Las fibras empleadas han sido de dos tipos: fibras de acero de $30 \mathrm{~mm}$ de longitud y 0,67 mm de diámetro, con extremos conformados; y fibras sintéticas de poliéster con $30 \mathrm{~mm}$ de longitud y 1,2 mm de espesor. Para la aplicación de rehabilitación, no es determinante una u otra fibra, ya que se supone estará en entornos protegidos.

- Los otros materiales han sido: cemento Portland CEM II/A-L 42,5 R, aditivos químicos utilizados fueron un plastificante polifuncional y un superplastificante de alto rendimiento a base de policarboxilatos. Ese último se ha mostrado eficiente en el control de la segregación cuando hormigones con materiales componentes de densidades muy distintas son producidos (13). Aun así, por último se ha utilizado un aditivo cohesionante, para garantizar la reducción del riesgo de segregación de la mezcla.

La Tabla 4 presenta las dosificaciones de los hormigones estudiados. En ella, se puede observar que hay tres of magnitude of the variables involved in the design of the structural elements and the concrete. In fact, the values adopted for the calculation are higher than the usual ones for real structures. Indeed, with the purpose of verifying the viability of the material, the established requirements are: a slump flow diameter of $600 \pm 50$ $\mathrm{mm}$ at the fresh state, a density lower than $1700 \mathrm{~kg} / \mathrm{m}^{3}$ at the hardened state and a minimum compressive strength of $20 \mathrm{MPa}$, at 28 days.

\section{EXPERIMENTAL CAMPAIGN}

Once the order of magnitude of the concrete requirements was established, an experimental campaign was performed to analyse the viability of the HLACF.

\subsection{Materials and mix design}

The selected materials for the experimental campaign are:

- As coarse aggregates: lightweight aggregates of expanded clay from two different plants of the same brand. One has a spherical form and the other, a more oval one. Besides, two ranges of size distribution were used, 3-10 $\mathrm{mm}$ and 6-16 $\mathrm{mm}$, which correspond to the densities of (550 \pm 50$)$ $\mathrm{kg} / \mathrm{m}^{3}$ and $(325 \pm 50) \mathrm{kg} / \mathrm{m}^{3}$, respectively. These aggregates had been added to the mixture on a dry condition, without previous saturation.

- 0-4 mm sand and 4-10 $\mathrm{mm}$ gravel have been used as natural aggregates. They are both crushed and limestone aggregates. Limestone filler has also been used as mineral admixture to improve the workability and the self-compactability.

- Two types of fibres have been used: steel fibres with a length of $30 \mathrm{~mm}$ and a diameter of $0.67 \mathrm{~mm}$, with formed ends; and waved synthetic fibres (polyester) with a length of $30 \mathrm{~mm}$ and a thickness of $1.2 \mathrm{~mm}$. For the application considered, both types of fibres can be used because they will be protected by the concrete.

- The other materials are: Portland cement CEM II/A-L $42.5 R$, the chemical admixtures are a plasticizer and a superplasticizer of polycarboxylate base. This last admixture has been proved to be efficient on the control of segregation when a concrete with component materials of very different densities is produced (13). Finally, a viscosity modifier admixture is also used to guarantee the reduction of concrete segregation.

Table 4 shows the dosage of the component materials used to produce the studied concretes. Three series can 
series: la serie 1 tiene el objetivo de evaluar la influencia del contenido de fíller, mientras que en la serie 2 el objetivo es analizar la influencia del esqueleto granular modificado con respecto a las pruebas anteriores. Asimismo, se busca evaluar la influencia del aditivo cohesionante y del tipo de fibra. La serie 3 tiene por objetivo verificar los cambios producidos al utilizar un árido ligero de diferente procedencia, por ello las pruebas $\mathrm{P}_{7}$ y $\mathrm{P}_{8}$ son iguales, pero fabricadas con diferentes áridos ligeros. Los resultados de esa última evaluación han demandado aumento de fluidez, lo que ha conducido al aumento de la cantidad de fíller en la prueba $P_{9}$.

Los esqueletos granulares propuestos ocupan aproximadamente $70 \%$ (esqueleto granular $A$, serie 1) y $63 \%$ (esqueleto granular $B$, series 2 y 3 ) del volumen de hormigón. Los áridos gruesos ocupan cerca de $45 \%$ del volumen total. En general, el volumen de árido grueso presente en HAC es más bajo que el utilizado aquí (14). Sin embargo, en el caso del HLACF ha sido importante incidir sobre el aumento del volumen de árido grueso, debido a que esos son los áridos ligeros que reducen la densidad del hormigón. En dicha tabla puede verse que el peso en fresco de estos hormigones, a partir de la prueba $\mathrm{P}_{4}$, se ha situado claramente por debajo del valor inicialmente requerido en aras a llevar al extremo las posibilidades de estos nuevos hormigones. be observed: series 1 has the purpose of evaluating the influence of the filler content, while series 2 seeks to investigate the effect of a modified granular skeleton. What is more, the influence of the viscosity modifier admixture and the fibres are also analysed. Series 3 has the objective of examining the changes produced when lightweight aggregates of different sources are used. For this reason, the mix proportions $P_{7}$ and $P_{8}$ are the same, but produced with different aggregates. The results from this last evaluation have demanded an increase in fluidity, and for that reason, the filler content has been raised in $P_{9}$.

The granular skeletons proposed occupy approximately $70 \%$ (granular skeleton $A$, series 1 ) and $63 \%$ (granular skeleton $B$, series 2 and 3 ) of the concrete volume. The coarse aggregates occupy around $45 \%$ of the total volume. Generally, the volume of the coarse aggregates in SCC is lower (14). However, for the HLACF it is important to raise the volume of coarse aggregates because these are responsible for reducing the density of the concrete. Table 4 shows that the fresh density of the concretes from mix proportions $\mathrm{P}_{4}$ to $\mathrm{P}_{9}$ is clearly below the specified value. This fact enables the full exploration of the possibilities of this new concrete.

Tabla 4 / Table 4

Dosificaciones estudiadas (en $\mathrm{kg} / \mathrm{m}^{3}$ ), en que $P_{\mathrm{i}}$ son las pruebas 1 , 2, etc. Studied proportions $\left(\mathrm{kg} / \mathrm{m}^{3}\right)$, where $P_{i}$ is mix proportions 1 , 2, etc.

\begin{tabular}{|c|c|c|c|c|c|c|c|c|c|}
\hline \multirow{2}{*}{ Materiales / Materials (kg/m $\mathbf{m}^{3}$} & \multicolumn{3}{|c|}{ Serie 1/ Series 1 } & \multicolumn{3}{c|}{ Serie 2 / Series 2 } & \multicolumn{3}{c|}{ Serie 3 / Series 3 } \\
\cline { 2 - 10 } & $\mathbf{P}_{\mathbf{1}}$ & $\mathbf{P}_{\mathbf{2}}$ & $\mathbf{P}_{\mathbf{3}}$ & $\mathbf{P}_{\mathbf{4}}$ & $\mathbf{P}_{\mathbf{5}}$ & $\mathbf{P}_{\mathbf{6}}$ & $\mathbf{P}_{\mathbf{7}}$ & $\mathbf{P}_{\mathbf{8}}$ & $\mathbf{P}_{\mathbf{9}}$ \\
\hline Arena 0-4 mm / Sand 0-4 mm & 774 & 774 & 774 & 500 & 500 & 500 & 500 & 500 & 500 \\
\hline Gravilla 4-10 mm / Grave/ 4-10 mm & 206 & 206 & 206 & 80 & 80 & 80 & 80 & 80 & 80 \\
\hline $\begin{array}{c}\text { Árido ligero 3-10 mm / Lightweight } \\
\text { aggregate 3-10 mm }\end{array}$ & 228 & 228 & 228 & 85 & 85 & 85 & 85 & 85 & 85 \\
\hline $\begin{array}{c}\text { Árido ligero 6-16 mm / Lightweight } \\
\text { aggregate 6-16 mm }\end{array}$ & - & - & - & 90 & 90 & 90 & 90 & 90 & 85 \\
\hline Cemento / Cement & 450 & 405 & 360 & 450 & 450 & 450 & 450 & 450 & 450 \\
\hline Fíller calcáreo / Limestone fíller & - & 45 & 90 & 75 & 75 & 75 & 75 & 75 & 100 \\
\hline Fibras acero / Steel fibres & 40 & 40 & 40 & 40 & 40 & - & - & - & - \\
\hline Fibras sintéticas / Synthetic fibres & - & - & - & - & - & 6 & 6 & 6 & 6 \\
\hline Agua / Water (I/m3) & 188 & 188 & 188 & 183 & 203 & 203 & 203 & 203 & 203 \\
\hline Plastificante / Plasticizer & 2.7 & 2.7 & 2.7 & 2.7 & 2.7 & 2.7 & 2.7 & 2.7 & 2.7 \\
\hline Superplastificante / Superplasticizer & 8.73 & 8.73 & 8.73 & 8.73 & 8.73 & 8.73 & 8.73 & 8.73 & 8.73 \\
\hline Cohesionante / Viscosity modifier & - & - & - & - & 1 & 1 & 0.85 & 0.85 & 0.85 \\
\hline Total / Total & 1897 & 1897 & 1897 & 1514 & 1535 & 1501 & 1501 & 1501 & 1521 \\
\hline
\end{tabular}

\subsection{Producción}

En cada prueba se han hecho amasadas de 100 litros, suficientes para los ensayos de caracterización del hormigón en estado fresco y endurecido. El amasado se ha hecho en una amasadora de eje vertical de 250 litros de

\subsection{Production}

For each dosage studied, a 100 litres of concrete was produced, enough for the characterization in fresh and hardened state. The mix was produced in a vertical axis mixer of 250 litres of maximum capacity. The addition of 
capacidad máxima. El vertido de los componentes ha sido manual y en orden inverso al tamaño del árido; empezando por los áridos gruesos en seco, hasta el cemento y el fíller calcáreo. Se ha mezclado en seco (30 segundos) para homogeneizar y luego se añade las fibras, con la amasadora en movimiento. En las pruebas en que se ha utilizado el aditivo cohesionante, se ha adicionado el mismo en seco. Antes de verter el agua (mezcla de 1 minuto) se ha dejado 2 litros, los cuales han sido añadidos juntamente con los aditivos plastificante (mezcla de 1 minuto) y superplastificante (mezcla de 4 minutos). La razón de ser radica en mejorar la dispersión de esos aditivos químicos.

\subsection{Caracterización del hormigón}

Los ensayos propuestos para caracterización del hormigón, tanto en estado fresco como en endurecido, y las normativas de referencia se presentan en la Tabla 5. component materials was manual and in a reverse order of grain size, starting with dry coarse aggregates and fine aggregates, and following with the cement and the limestone filler. A dry mixture was first produced (30 seconds) to homogenize and after that, the fibres were added with the mixer moving. In the concretes where the viscosity modifier admixture was used, it was added at the dry state. Before adding water (1 minute mixture) 2 litres were separated to be added along with the plasticizer (1 minute mixture) and the superplasticizer (4 minutes mixture). Its purpose is to improve the dispersion of these chemical admixtures.

\subsection{Concrete characterization}

Table 5 presents the tests to characterize the concrete in fresh and in hardened state and also the reference standards.

Tabla 5 / Table 5

Ensayos realizados y normativas de referencia. Performed tests and reference standards.

\begin{tabular}{|c|c|c|c|}
\hline \multicolumn{2}{|c|}{ Estado fresco / Fresh state } & \multicolumn{2}{c|}{ Estado endurecido / Hardened state } \\
\hline Densidad / Density & UNE-EN 12350-6: 2006 (15) & Densidad / Density & UNE-EN 12390-7: 2001 (19) \\
\hline Escurrimiento / Slump flow & UNE 83361: 2007 (16) & $\begin{array}{c}\text { Resistencia a compresión / } \\
\text { Compressive strength }\end{array}$ & UNE 12390-3: 2003 (20) \\
\hline $\begin{array}{c}\text { Escurrimiento con el anillo japonés / } \\
\text { Slump flow with the Japanese ring }\end{array}$ & UNE 83362: 2007 (17) & $\begin{array}{c}\text { Resistencia a tracción / Tensile } \\
\text { strength }\end{array}$ & UNE 83515: 2007 (21) \\
\hline Aire ocluido / Incorporated air & UNE-EN 12350-2: 2006 (18) & - & - \\
\hline
\end{tabular}

\section{RESULTADOS}

\subsection{Resultados obtenidos}

En la Figura 5 se presentan los resultados obtenidos en estado fresco. En el eje $x$ se presentan las variables evaluadas en cada serie y las pruebas que llevan el aditivo cohesionante, mientras que en ordenada se presentan los resultados del escurrimiento (sin y con anillo japonés en $\mathrm{mm}$ ) y del aire ocluido (en \%). Esta propiedad no fue realizada en las pruebas $P_{1}, P_{2}$ y $P_{3}$, por no disposición del equipo de medición. Para las demás pruebas se observan resultados elevados, tal como era de esperar al tratarse de áridos ligeros incorporados en seco. En esa figura, y también en la Figura 6, las siglas VMA y LWA significan aditivo cohesionante y árido ligero, respectivamente.

La Figura 6 presenta los resultados de los ensayos de resistencia a compresión, contrastados con la densidad en estado endurecido (en ordenadas). En el eje $x$ se presentan las variables evaluadas en cada serie y las pruebas que llevan los esqueletos granulares base A y B.

\section{RESULTS}

\subsection{Obtained results}

Figure 5 presents the results at the fresh state. Axis $x$ shows the evaluated variables at each series and the mix proportions in which the viscosity modifier admixture was used. Axis y shows the results of the slump flow (with and without the Japanese ring; in $\mathrm{mm}$ ) and the percentage of incorporated air. This last property was not evaluated for concretes from $P_{1}, P_{2}$ and $P_{3}$ because the measuring equipment was unavailable at the time. For the other mix proportions studied, the results are high, as a consequence of the addition of lightweight aggregates at the dry state. In this figure, and also in Figure 6, the letters VMA and LWA mean viscosity modifier admixture and lightweight aggregate, respectively.

Figure 6 shows the results of the compressive strength contrasted with the density at the hardened state (axis $y)$. In axis $x$, the variables evaluated at each series are presented as well as the mix proportions in which the granular skeletons $A$ and $B$ were used. 


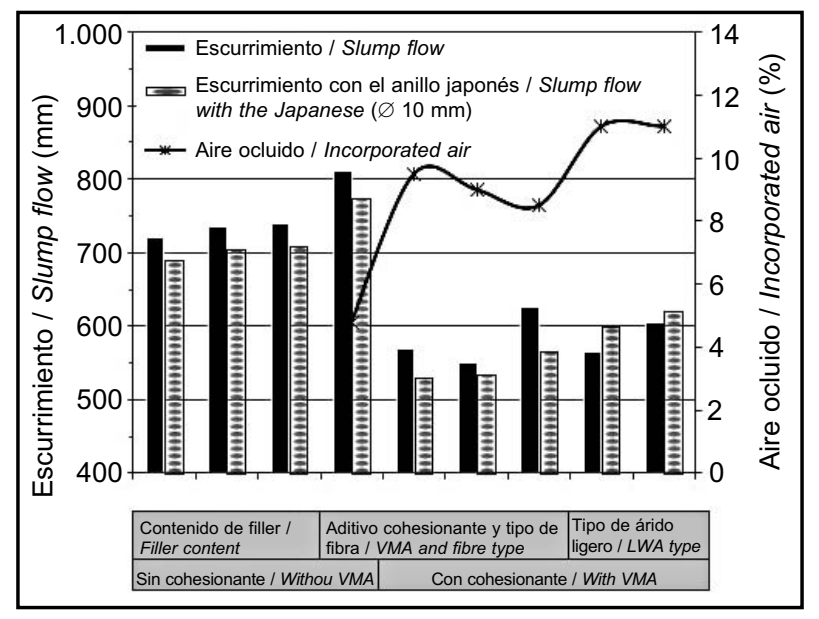

Figura 5. Resultados en estado fresco. Figure 5. Results at the fresh state.

En la Figura 7 se presentan los resultados de la resistencia a tracción indirecta obtenidos en el ensayo Barcelona (UNE 83515: 08). En ella, puede verse que no se presentan los resultados para las pruebas $P_{1}$ hasta $P_{4}$, lo cual responde a que en esas primeras pruebas, la determinación se hizo mediante el ensayo brasileño (UNE 83306: 1985). En abscisas de esta figura se presenta la deformación circunferencial (en $\mathrm{mm}$ ) y la resistencia que se obtiene para dichos valores, esto es, resistencias residuales (22).

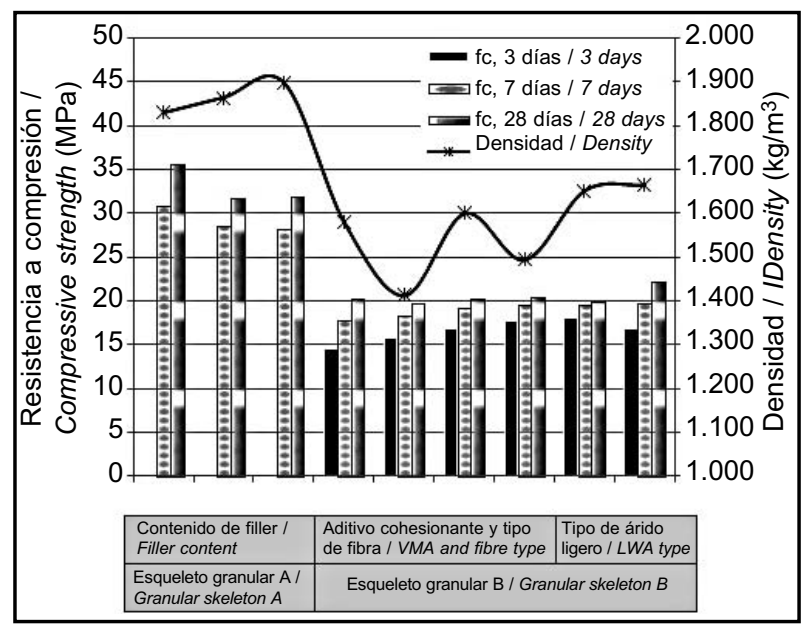

Figura 6. Resultados en estado endurecido, resistencia a compresión y densidad.

Figure 6. Results at the hardened state, compressive strength and density.

Figure 7 gives the results of the tensile strength obtained by the Barcelona test (UNE 83515: 08). The results are not given for proportions $P_{1}$ to $P_{4}$ because for these proportions the determination of tensile strength was made by the Brazilian test (UNE 83306: 1985). In axis $x$ of this figure, the circumferential deformation is presented (in $\mathrm{mm}$ ) while the tensile strength obtained for the respective deformation is given in axis $y$, also called residual strength (22).

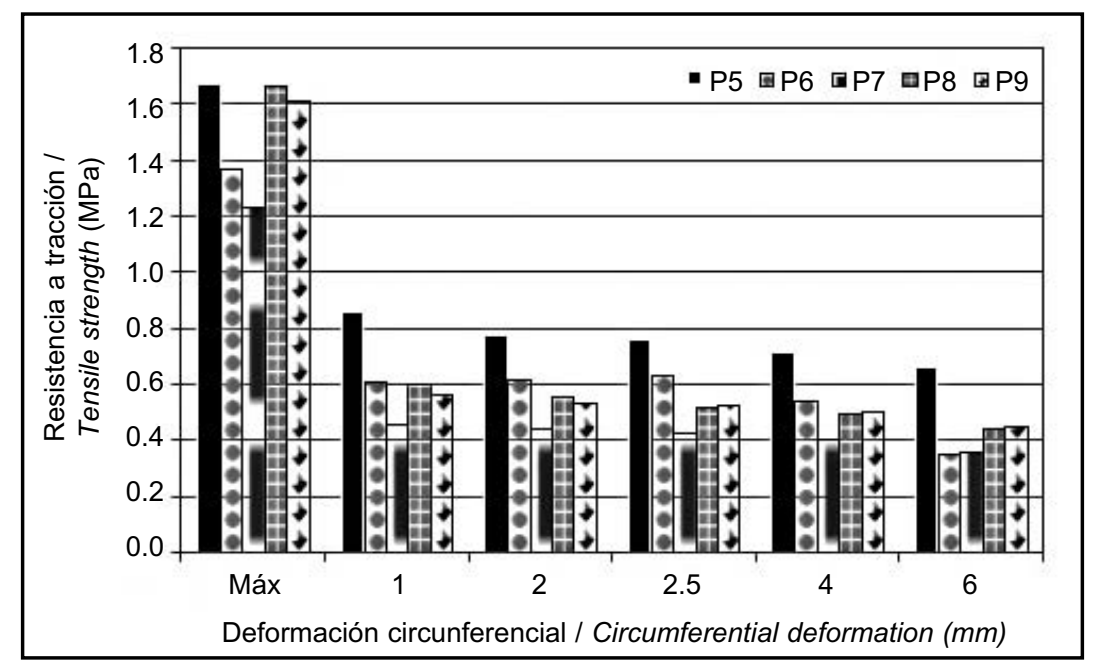

Figura 7. Resultados en estado endurecido, resistencia a tracción. Figure 7. Results at the hardened state, tensile strength.

En dicha Figura 7 se observa que el hormigón con fibras de acero $\left(P_{5}\right)$ presenta resistencias a tracción residuales más elevadas que los hormigones con fibras de poliéster, para cualquier valor de la deformación circunferencial. Ese comportamiento responde, en este caso, a que las fibras de acero tienen un sistema de anclaje más eficiente
Figure 7 shows that the concrete with steel fibres $\left(P_{5}\right)$ presents residual tensile strengths higher than those of concretes with polyester fibres. This behaviour is due to the anchorage system of the steel fibres, which is more efficient than that of synthetic fibres. Other studies have already revealed that the residual strength is under the 
que el de las fibras sintéticas. En otros estudios ya se ha verificado que la resistencia residual está bajo influencia del sistema de anclaje. Se ha observado que hormigones producidos con fibras de acero con extremos conformados presentan resistencias residuales superiores a los hormigones que llevan fibras de acero con extremos achatados, y que esos dos tipos de fibras confieren resistencia superior a la conferida por las fibras plásticas onduladas (23).

En la Tabla 6 se presentan los resultados de la densidad tanto en estado fresco como en estado endurecido; para este último el desmoldeo se ha considerado a las 24 horas. En ésta puede verse que la densidad en estado endurecido es superior a la densidad en estado fresco en siete de las nueve pruebas. Ese aumento puede deberse a que, en estado fresco, el recipiente utilizado para la determinación del volumen y de la masa del hormigón tiene una mayor capacidad que la probeta (utilizada para el ensayo en estado endurecido). Asimismo, para liberar parte del aire ocluido y aumentar la compacidad, se ha aplicado energía a través de golpes en los moldes de las probetas. influence of the anchorage system. It has been observed that concretes produced with steel fibres present higher residual strength when the ends of the fibre are formed, and lower strength when the ends are flattened. Likewise, both steel-fibres types provide a higher strength than the one given by waved plastic fibres (23).

Table 6 shows the density results at fresh and hardened state, at the age of 24 hours. It is possible to observe that the density at the hardened state is higher than the density at the fresh state in seven of the nine studied concretes. This increase may be due to the fact that the container used to determine the volume and the mass of the concrete at the fresh state had a larger capacity than that of the mould of a specimen (used for the determination at the hardened state). Moreover, to release part of the occluded air and increase the compactness, energy was applied to the specimen moulds with a few hits at the time of casting.

Tabla 6 / Table 6

Resultados de densidad $\left(\mathrm{en} \mathrm{kg} / \mathrm{m}^{3}\right)$. Results of density $\left(\mathrm{kg} / \mathrm{m}^{3}\right)$.

\begin{tabular}{|c|c|c|c|c|c|c|c|c|c|}
\hline \multirow{2}{*}{ Ensayos / Tests } & \multicolumn{3}{|c|}{ Serie 1/ Series 1 } & \multicolumn{3}{c|}{ Serie 2 / Series 2 } & \multicolumn{2}{c|}{ Serie 3 / Series 3 } \\
\cline { 2 - 10 } & $\mathbf{P}_{\mathbf{1}}$ & $\mathbf{P}_{\mathbf{2}}$ & $\mathbf{P}_{\mathbf{3}}$ & $\mathbf{P}_{\mathbf{4}}$ & $\mathbf{P}_{\mathbf{5}}$ & $\mathbf{P}_{\mathbf{6}}$ & $\mathbf{P}_{\mathbf{7}}$ & $\mathbf{P}_{\mathbf{8}}$ & $\mathbf{P}_{\mathbf{9}}$ \\
\hline Estado fresco / Fresh state & 1743 & 1652 & 1683 & 1590 & 1469 & 1575 & 1386 & 1500 & 1525 \\
\hline Estado endurecido / Hardened state & 1830 & 1864 & 1897 & 1579 & 1413 & 1600 & 1494 & 1652 & 1665 \\
\hline
\end{tabular}

\subsection{Análisis de los resultados por variables}

Para analizar la influencia del contenido de filler calizo se realizaron las pruebas $\mathrm{P}_{1}, \mathrm{P}_{2}$ y $\mathrm{P}_{3}$. En estado fresco, estas series presentan elevada fluidez (por encima de los $700 \mathrm{~mm}$ ), si bien se observa una tendencia a la segregación de las mezclas, con los áridos ligeros propensos a flotar. Asimismo, se observa un pequeño aumento del diámetro de escurrimiento a medida que el fíller se incorpora a las mezclas (inferior a $5 \%$ en cada caso), manteniéndose en los ensayos con el anillo japonés y, por otro lado, una ligera pérdida de resistencia.

La razón para el comportamiento observado obedece a que dada la menor superficie específica del filler respecto al cemento, al aumentar el contenido de filler, tenemos más agua disponible por lo que aumentase la trabajabilidad, por un lado y disminuyese la resistencia (del orden de un $11 \%$, a los 28 días), al aumentar la relación agua/cemento (pasa de 0,42 en la $\mathrm{P}_{1}$ a 0,52 en la $\mathrm{P}_{3}$ ). La disminución de resistencia es menos significativa que lo que podría señalar la variación de la relación

\subsection{Result analysis by variables}

To analyse the influence of the limestone filler content, the mix proportions $P_{1}, P_{2}$ and $P_{3}$ were tested. Although these concretes present high fluidity at the fresh state (a slump flow over $700 \mathrm{~mm}$ ), they also show a tendency for segregation, and the lightweight aggregates are likely to float in the mass of concrete. Nevertheless, a small increase in the diameter of the slump flow was verified as the filler was added to the concretes (less than $5 \%$ in each situation). This trend is kept in the slump flow tests with the Japanese ring. On the other hand, a small reduction in the strength value was simultaneously observed.

The reason for this behaviour is centred in the specific surface of the filler, which is smaller than that of the cement. When the filler content is increased, the amount of water available in the mixture also increases. Consequently, the workability improves and the strength decreases (around $11 \%$ at 28 days) as a result of the higher water/cement ratio (it goes from 0.42 in the $P_{1}$ to 0.52 in the $\left.P_{3}\right)$. The strength decrease could be much higher considering the variation observed in the 
agua/cemento fruto del efecto favorable del empaquetamiento que aporta el filler, lo que se verifica en el aumento de densidad (véanse Tabla 6 y Figura 6).

A raíz de los resultados de estas tres primeras pruebas se vio la necesidad de emplear el aditivo cohesionante, para evitar los inicios de segregación y, al mismo tiempo, incorporar un árido ligero de mayor tamaño para conseguir disminuir la densidad.

En la citada Figura 5 puede verse que la incorporación del cohesionante (en las pruebas $\mathrm{P}_{5}$ a $\mathrm{P}_{9}$ ) reduce de forma significativa el valor medio de la extensión de flujo (del orden del $20 \%$ ). En el ámbito de valores considerados $\left(0,85\right.$ a $\left.1 \mathrm{~kg} / \mathrm{m}^{3}\right)$, parece que se alcanza el punto de saturación, ya que no se aprecia diferencias significativas. La adopción de valores inferiores a los señalados $\left(0,85<\right.$ contenido de aditivo $\left.<1 \mathrm{~kg} / \mathrm{m}^{3}\right)$ conduciría a valores intermedios de extensión de flujos entre las pruebas $\mathrm{P}_{1}$ a $\mathrm{P}_{4}$ y las pruebas $\mathrm{P}_{5}$ a $\mathrm{P}_{9}$, tal como se observa en los resultados de las pruebas $\mathrm{P}_{6}$ y $\mathrm{P}_{7}$, que sólo se diferencian en la cantidad de cohesionante.

El efecto del cohesionante también se observa en la aparición de segregación y retención en el anillo japonés. Así, en la Figura 8 se muestra los ensayos de escurrimiento con el anillo japonés de las pruebas $\mathrm{P}_{4}$ y $\mathrm{P}_{5}$, las cuales tienen el mismo esqueleto granular si bien una incorpora el cohesionante $\left(P_{5}\right)$ y la otra no $\left(P_{4}\right)$. Puede verse que la prueba $\mathrm{P}_{4}$ presenta segregación, exudación en el labio de avance y gran retención en el anillo japonés, lo que no se refleja en la prueba $\mathrm{P}_{5}$, que conduce a una extensión homogénea y sin retenciones en el anillo japonés. No obstante, hay que señalar que la prueba $P_{5}$ requiere una cantidad mayor de agua, ya que el aditivo se presenta en forma de polvo de gran finura. water/cement ratio. Nevertheless, the filler packing effect counterbalances the situation and is favourable to the concrete strength. It is also responsible for the density increase (see Table 6 and Figure 6).

These first series pointed out the necessity of using a viscosity modifier admixture in order to avoid segregation. That would also allow the incorporation of a lightweight aggregate with larger grains, which would provide lower density.

In the above-mentioned Figure 5 it is possible to observe that the incorporation of a viscosity modifier admixture (in mix proportions $P_{5}$ to $P_{9}$ ) reduces significantly the results of the slump flow test (around 20\%). Considering the scope of values (from 0.85 to $1 \mathrm{~kg} / \mathrm{m}^{3}$ ), it seems that the saturation point of the admixture is reached as significant variations in results are not observed. The adoption of a lower admixture content $\left(0.85<\right.$ admixture content $\left.<1 \mathrm{~kg} / \mathrm{m}^{3}\right)$ would lead to intermediary results of slump flow among the ones obtained for concretes from $P_{1}$ to $P_{4}$ and $P_{5}$ to $P_{9}$. That can be observed in mix proportions $P_{6}$ and $P_{7}$, which differ only in the amount of viscosity modifier admixture.

The effect of the viscosity modifier admixture can also be verified in the appearance of segregation and blockage in the Japanese ring. Figure 8 shows the slump flow test with the Japanese ring for concretes $P_{4}$ and $P_{5}$, where both mix proportions have the same granular skeleton, but only mix proportion $P_{5}$ presents the admixture in its composition. It can be observed that the concrete from $P_{4}$ presents segregation, bleeding and great blockage inside the Japanese ring. The same behaviour cannot be seen in the concrete from $P_{5}$, because it is homogeneous and is not blocked by the ring bars. Nevertheless, the concrete from $P_{5}$ needs a higher amount of water because the viscosity modifier admixture is a powder of great fineness.

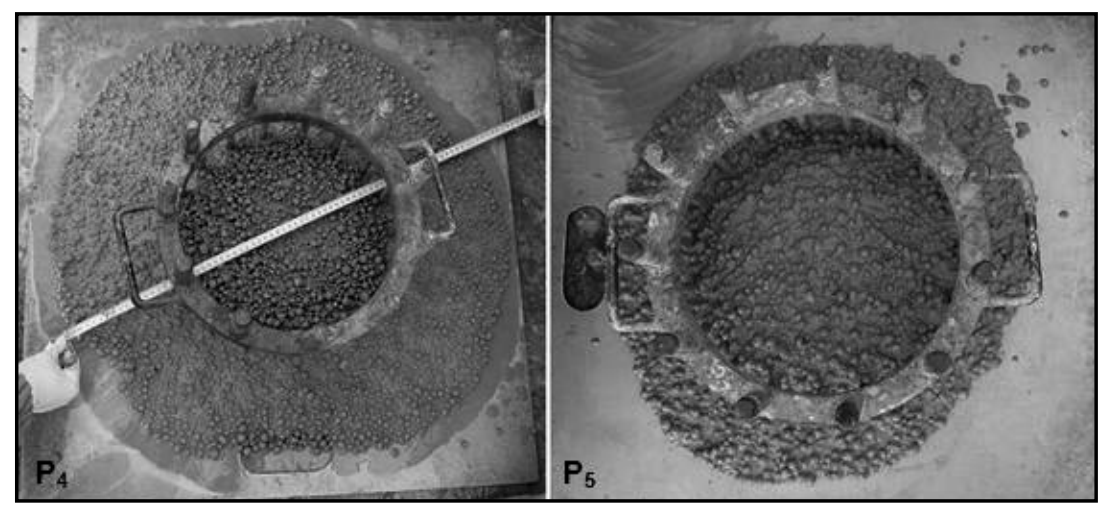

Figura 8. Ensayo de escurrimiento con el anillo japonés, pruebas $\mathrm{P}_{4}$ y $\mathrm{P}_{5}$. Figure 8. Slump flow test with the Japanese ring, concretes $P_{4}$ and $P_{5}$.

Desde el punto de vista de las propiedades del hormigón endurecido, el efecto del cohesionante es menor tal
At the hardened state, the effect of the viscosity modifier admixture is lower, as can be seen in the Figure 6 
como puede verse en la Figura 6 anteriormente presentada, en la que la resistencia a compresión a 28 días se mantiene muy similar en todas las pruebas. Como resultado cabe señalar la importancia vital que tiene la incorporación de dicho aditivo en la obtención de un HLACF, especialmente en las propiedades del hormigón en estado fresco, al hacer compatible propiedades inicialmente contrapuestas aportadas por los distintos componentes.

Los resultados de las pruebas $\mathrm{P}_{1}$ a $\mathrm{P}_{3}$ condujeron, tal como se ha dicho, a la necesidad de emplear un aditivo cohesionante, cuya influencia se ha analizado, y a la necesidad de cambiar el esqueleto granular, lo cual se hizo a partir de la prueba $\mathrm{P}_{4}$, intentando bajar la densidad del hormigón. Las modificaciones realizadas consisten en la disminución del consumo de los áridos naturales y del árido ligero 3-10 mm $\left(550 \mathrm{~kg} / \mathrm{m}^{3}\right)$, con incorporación del árido ligero $6-16 \mathrm{~mm}\left(325 \mathrm{~kg} / \mathrm{m}^{3}\right)$ y del fíller calcáreo, sin que ese sustituya al cemento. El resultado ha sido la disminución del total de áridos en $37,5 \%$, en masa, y $7,0 \%$, en volumen.

En estado fresco, se observa un aumento de la fluidez del hormigón, resultado del conjunto de medidas adoptadas en la modificación del esqueleto granular, tales como la incorporación del fíller y también la disminución del consumo de la arena 0-4 mm. La tendencia a la segregación se confirma en la prueba $\mathrm{P}_{4}$, lo que indica la necesidad de mejorar la cohesión tal como se muestra en la Figura $8\left(\mathrm{P}_{4}\right)$.

En estado endurecido, se obtienen disminuciones significativas en la densidad, y consecuentemente, en la resistencia a compresión. Las densidades superiores a los $1.800 \mathrm{~kg} / \mathrm{m}^{3}$ en las tres primeras pruebas bajan a valores medios próximos a los $1.600 \mathrm{~kg} / \mathrm{m}^{3}$. La resistencia a compresión disminuye a valores medios próximos a los $20 \mathrm{MPa}$, a los 28 días.

La verificación de la influencia del tipo de fibra se realiza a través de las pruebas $P_{5}$ y $P_{6}$. El cambio de las fibras de acero $\left(P_{5}\right)$ por las fibras de sintéticas $\left(P_{6}\right)$ da lugar a una pequeña reducción de la fluidez $(3,5 \%)$. Ello puede ser consecuencia no sólo del material (mayor rugosidad de las fibras de poliéster), sino también de la esbeltez, ya que es mayor en las fibras sintéticas. Sin embargo, la presencia del anillo japonés produce una disminución del diámetro de escurrimiento más elevada en el hormigón con fibras de acero, lo que indica mayor resistencia al bloqueo, que podría ser fruto de la mayor rigidez de esas fibras.

En estado endurecido, el efecto del cambio en el tipo de fibra se plasma, no tanto en la resistencia a compresión, sino en la resistencia a tracción. Los resultados muestran que, aunque la resistencia a compresión sea algo más previously presented. An indication of it is the compressive strength at 28 days, which is very similar for all the concretes studied. However, it is important to highlight the vital importance of the viscosity modifier admixture in the production of the HLACF, especially at the fresh state, because the properties which were initially in conflict became compatible.

The results obtained for the concretes from $P_{1}$ to $P_{3}$ lead to the incorporation of the viscosity modifier admixture and to changes on the granular skeleton, which was made starting from mix proportion $\mathrm{P}_{4}$ with the intention of reducing concrete density. The changes performed consist of the reduction of natural aggregates and 3-10 $\mathrm{mm}\left(550 \mathrm{~kg} / \mathrm{m}^{3}\right)$ lightweight aggregate content, with the incorporation of $6-16 \mathrm{~mm}\left(325 \mathrm{~kg} / \mathrm{m}^{3}\right)$ lightweight aggregate and limestone filler, without substituting cement. As a final result, the total amount of aggregates was reduced a $37.5 \%$ in mass, and a $7.0 \%$ in volume.

At the fresh state, an increase in the concrete fluidity can be observed as a result of the measures adopted in the modification of the granular skeleton, such as the filler incorporation and the reduction on the $0-4 \mathrm{~mm}$ sand content. The tendency to segregation is confirmed in the concrete from $P_{4}$, which points out the need for improving the cohesion, as can be seen in Figure $8\left(P_{4}\right)$.

At the hardened state, significant reductions on density are observed and as a consequence, compressive strength also decreases. The values of density around $1800 \mathrm{~kg} / \mathrm{m}^{3}$ obtained on the first series $\left(P_{1}\right.$ to $\left.P_{3}\right)$ are reduced to values around $1600 \mathrm{~kg} / \mathrm{m}^{3}$. The compressive strength decreases to values around $20 \mathrm{MPa}$ at 28 days.

The influence of the type of fibre is verified through the concretes from mix proportions $P_{5}$ and $P_{6}$. The change from steel fibres $\left(P_{5}\right)$ to synthetic fibres $\left(P_{6}\right)$ produces a small reduction on fluidity (3.5\%). This can be a consequence not only of the material (the higher roughness of polyester fibres) but also of the fibre aspect ratio, which is higher for the synthetic fibres. However, the results of the slump flow test with the Japanese ring show higher reduction of diameters for concretes with steel fibres, which indicates a higher blockage. This could be the result of the higher stiffness of the steel fibres when compared to the synthetic ones.

At the hardened state, the effect of the fibre type is reflected not on the compressive strength, but on the tensile strength. The results show that the compressive strength is a little bit higher for concrete with synthetic 
elevada para el hormigón con fibras sintéticas (apenas $2,5 \%$ ), no ocurre lo mismo para la resistencia a tracción. Esta última presenta un valor máximo un $18 \%$ superior en el hormigón con fibras de acero respecto al hormigón con fibras sintéticas.

Las resistencias residuales también son más elevadas en los hormigones con fibras de acero (véase Figura 7), lo cual es importante en la contribución estructural. Ello se justifica no tanto por las diferentes resistencias de cada material (las fibras de acero presentan resistencia a tracción del orden de $1.000 \mathrm{MPa}$ mientras la resistencia de las fibras de poliéster está entre 400 y $800 \mathrm{MPa}$ ), ya que las fibras no rompen. Así, la razón de ser principal de esta diferencia es el diferente comportamiento del anclaje de las fibras y de la adherencia de las mismas a la matriz de hormigón, los cuales resultan favorables, en este caso, a las fibras metálicas.

El árido ligero grueso empleado tuvo que cambiarse en el desarrollo de las pruebas como consecuencia de que el suministrado había cambiado el origen del mismo. Ello modifica, en cierta medida, la forma exterior del mismo (pasa de esférica a ovalada con un aumento de la porosidad superficial), tal como se observa en la Figura 9. Así, pues, era necesario analizar la influencia de la forma del árido ligero. Por ello en la prueba $\mathrm{P}_{8}$ se ha utilizado la misma dosificación de la $\mathrm{P}_{7}$, pero se ha cambiado la procedencia del árido ligero. fibres (only a 2.5\%). However, when it comes to tensile strength, the differences are more evident as the concrete with steel fibres presents a maximum tensile strength an $18 \%$ higher than that of the concrete with polyester fibres.

The residual tensile strengths are also higher for concretes with steel fibres (see Figure 7). This property is very important for the structure. The reason for this behaviour is centred not so much on the material strength of each fibre (steel fibres present a tensile strength around $1000 \mathrm{MPa}$, while the tensile strength of polyester fibres is between 400 and $800 \mathrm{MPa}$ ), because the fibres do not break. Thus, the main cause may be the efficiency of the anchorage system and the bounding of the fibres to the concrete matrix, which is favourable in this case to the steel fibres.

The coarse lightweight aggregate used had to be changed in the middle of the experimental campaign because its origin was also changed. The implication of this fact was the modification in the form of the grains (from a spherical to an oval form with an increase in the superficial porosity), as can be seen in Figure 9. Therefore, it became necessary to investigate the influences of the lightweight aggregate form of the grains on the concrete. This explains why concretes from $P_{7}$ and $P_{8}$ present the exact same proportions of component materials: the difference between the two concretes lies on the use of lightweight aggregates from different origins.

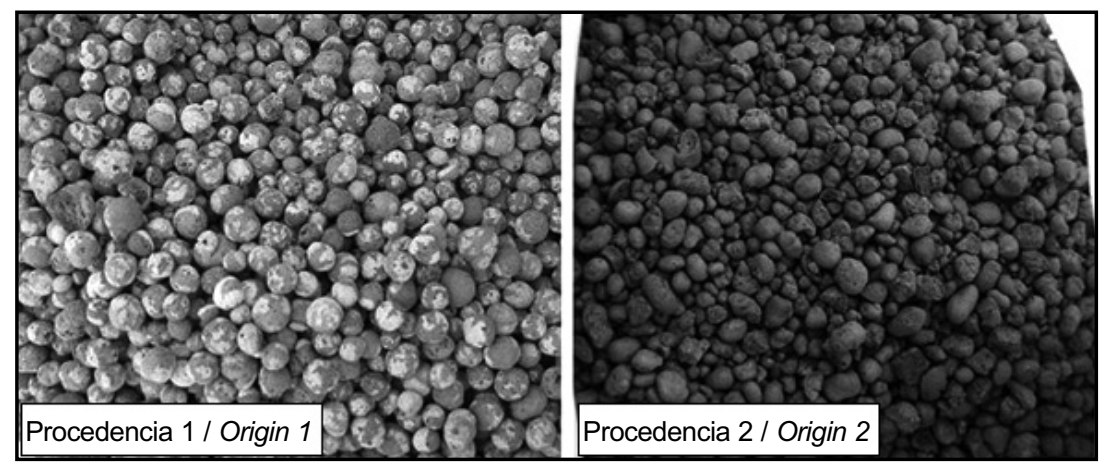

Figura 9. Áridos ligeros suministrados de distinto origen.

Figure 9. Lightweight aggregates from different origins.

Esos cambios tienen influencia en el comportamiento en fresco. El diámetro de escurrimiento baja aproximadamente $10 \%$ al cambiar el tipo de árido, reducción significativa a un HAC. En estado endurecido, el efecto del cambio del tipo de árido ligero no se observa en la resistencia a compresión, sino que en la resistencia a tracción. En la prueba $\mathrm{P}_{8}$ el hormigón presenta un aumento de resistencia a tracción próximo a $35 \%$, lo que puede deberse a que la forma ovalada produce mayor trabazón en comparación con el árido esférico.
The changes on the characteristics of aggregates influence the behavior of concrete at the fresh state. The slump flow diameter decreases approximately a $10 \%$ when the aggregate is changed, which is a significant value for an SCC. At the hardened state, the compressive strength does not change much regardless of the type of aggregate. On the other hand, the tensile strength is around a $35 \%$ higher in the concrete from $P_{8}$. It may be due to the oval form of the grains that produce greater interlocking than the spherical grains. 
Frente a todo eso, se ha realizado un pequeño ajuste en la dosificación del hormigón de la prueba $\mathrm{P}_{8}$, cara a aumentar la fluidez y posibilitar su aplicación. Así, en la prueba $\mathrm{P}_{9}$ se ha aumentado la cantidad de fíller, disminuyendo el consumo del árido ligero 6-16 $\mathrm{mm}$. Ello ha resultado favorable, y la pérdida de fluidez ocurrida al cambiar el tipo de árido $\left(\mathrm{P}_{8}\right.$ con respecto a $\left.\mathrm{P}_{7}\right)$ ha sido en gran parte recuperada. La Figura 10 muestra el aspecto del hormigón fresco a través de los ensayos de escurrimiento con el anillo japonés y el labio de avance, en la que se puede observar una buena distribución de masas, sin segregación.
Some adjustments were made in the concrete from $P_{8}$ in order to increase the fluidity and enable the use of the concrete for the required application. Thus, the component material proportions of concrete $P_{9}$ were modified: the amount of filler was increased and the 6$16 \mathrm{~mm}$ lightweight aggregate content was decreased. This measure resulted favourable and the fluidity lost when the lightweight aggregate was changed $\left(P_{8}\right.$ with respect to $P_{7}$ ) was recovered in great part. Figure 10 shows the slump flow test with the Japanese ring and the edge of the concrete. It is possible to observe a good mass distribution and a lack of segregation or bleeding.

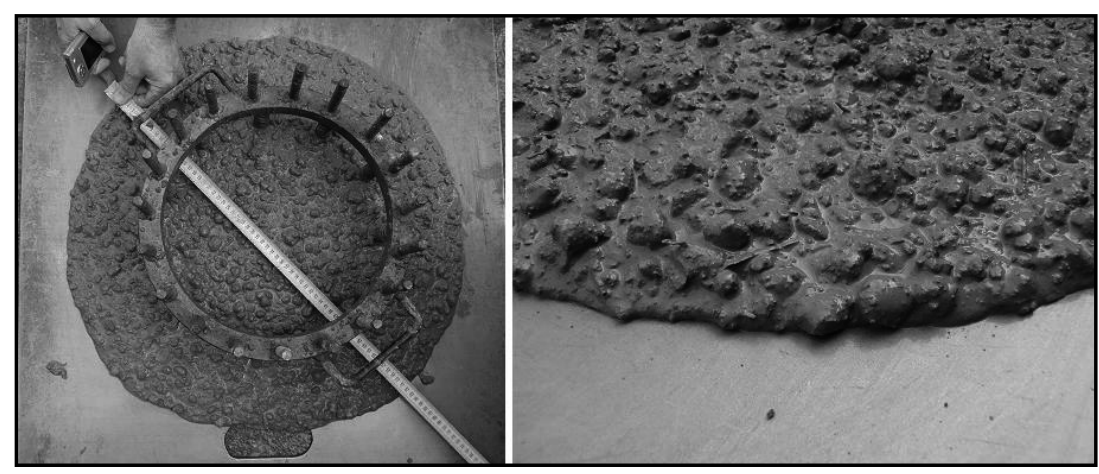

Figura 10. Ensayos de escurrimiento con el anillo japonés y labio de avance, prueba $P_{9}$. Figure 10. Slump flow test with the Japanese ring and the edge of concrete, concrete $P_{9}$.

En estado endurecido, se ha producido un ligero aumento en la resistencia a compresión, resultado de la mayor compacidad conferida por el aumento en el consumo de fíller calcáreo. En ningún caso, se ha observado segregación o exudación en esta última serie, presentando una buena distribución, tanto de los áridos ligeros como de las fibras. En consecuencia, ésta es la dosificación de partida que se ha probado con éxito desde el punto de vista industrial, habiendo superado una prueba de bombeo de la misma.

\section{CONCLUSIONES Y RECOMENDACIONES}

La conclusión más relevante de este artículo es que ha sido posible diseñar y fabricar un hormigón ligero autocompactante con fibras (prueba $\mathrm{P}_{9}$ ), que da respuesta satisfactoria a los requisitos planteados para un hormigón de rehabilitación desde diferentes puntos de vista: técnico y estructural, ambiental y social. En la literatura técnica consultada no se tiene constancia de un material de estas características, lo que ha permitido patentar el mismo. La variable principal del éxito es la incorporación de un aditivo cohesionante, ya que sin él se produce segregación de la mezcla.

Asimismo, debe destacarse la importancia del estudio estructural y seccional que permite acotar con rigor el
At the hardened state, a small increase in the compressive strength was observed, as a consequence of the improvements in the matrix compactness provided by the higher content of limestone filler. In these last series, no segregation or bleeding was verified, but the concrete proved itself homogeneous, with a good distribution of the lightweight aggregates and the fibres. For this reason, this mix proportion was tested at industrial scale and it had been properly pumped, presenting good results.

\section{CONCLUSIONS AND RECOMMENDATIONS}

The most relevant conclusion obtained is that it is possible to produce a lightweight self-compacting concrete reinforced with fibres (concrete $P_{g}$ ) to respond to the requirements established for a rehabilitation concrete, from different points of view: technical and structural, environmental and social. The technical literature consulted did not include any material with the characteristics reported in this paper, so that made it possible to patent this concrete. The main variable for the achieved success was the use of a viscosity modifier admixture, because otherwise the concrete mixture would present segregation.

Also, it is important to highlight the significance of the structural and sectional study performed, which made it 
rango de las principales variables estructurales. Estos estudios de comportamiento no lineales incorporan las directrices marcadas en el anejo 14 de la EHE 08 (24) sobre la visión estructural del hormigón con fibras, lo que abre una nueva vía para este tipo de hormigones.

Por último cabe señalar que con este tipo de hormigones ya se han realizado pruebas industriales sobre la viabilidad del bombeo de las mismas, habiendo sido un éxito, y se está en fase de aplicación a una obra real.

\section{AGRADECIMIENTOS}

Cualquier investigación experimental no es posible sin la colaboración de diferentes técnicos de laboratorio que la hagan posible, por ello se quiere agradecer la colaboración de los técnicos del laboratorio de PROMSA, así como a la propia empresa por la confianza depositada a lo largo de los años, en la realización de diferentes proyectos de investigación. possible to delimit rigorously the main structural variables. This non-linear study considers the guidelines presented in annex 14 of the EHE 08 (24) about the structural vision of concrete reinforced with fibres, which opens a new way for this type of concrete.

Finally, it should be mentioned that industrial pumping tests had already been performed with the concrete studied. The tests were a success and the material had proved itself viable for application. The next step that is being considered is the application of the concrete to the rehabilitation of a real structure.

\section{ACKNOWLEDGEMENTS}

No experimental investigation is possible without the collaboration of laboratory technicians. For this reason we would like to thank the collaboration of the technicians from the PROMSA laboratory, as well as the company itself for the trust received throughout the years, during the realization of different investigation projects.

\section{BIBLIOGRAFÍA / BIBLIOGRAPHY}

(1) Rasell Calamina, J.: "La construcció en l'arquitectura de Barcelona a finals del segle XVIII", Tesis doctoral dirigida por Pere Here, Barcelona, UPC, 1996.

(2) Paricio Casademunt, A.: "Analisi del sistema constructiu a base de murs de carrega, utilitzats en la formació de I' Eixample de Barcelona", Tesis doctoral dirigida por Fructuoso Maña. Departament de Construccions Arquitectòniques I. Barcelona, UPC, 1999.

(3) Haist, M.; Müller, H. S.: "Optimization of the pumpability of self-compacting lightweight concrete", The Second North American Conference on the Design and Use of Self-Consolidating Concrete, Chicago, s.n., 2005.

(4) Tasdemir, M. A.; Atahan, H. N.; Gokalp, I.; Yerlikaya, M.: "Comparison of workability and mechanical properties of normal and lightweight SCCS with and without steel fibers", The Third North American Conference on the Design and Use of Self-Consolidating Concrete, Chicago, s.n., 2008.

(5) Aguado, A.; Masó, D.; Klein, N. S.: "Hormigón autocompactante ligero con fibras estructurales para rehabilitación de forjados de edifícios", Patente, $\mathrm{n}^{\circ}$ de solicitud $\mathrm{P} 200902445$.

(6) BOE, 23/10/2007. Documento básico SE-AE Acciones en la edificación, 2007.

(7) Pujadas, P.: "Durabilidad del hormigón con fibras de polipropileno", Tesina de Especialidad (directores: Aguado de Cea, A.; Vandewalle, M.), Barcelona, UPC, 2008.

(8) Collins, M. P.; Mitchell, D.: "Prestressed Concrete Basics", Ontário, Canadian Prestressed Institute, 1987.

(9) RILEM. "Tests and Design Methods for Steel Fibre Reinforced Concrete, S.L.", Materials and Structures, 2003, vol. 36, 262, pp. 560567.

(10) Barros, J. A. O.; Cunha, V. M. C. F.; Ribeiro, A. F.; Antunes, J. A. B.: "Post-cracking behavior of steel fibre reinforced concrete", Materials and Structures. 2005, vol. 38, pp. 47-56. doi:10.1007/BF02480574

(11) De la Fuente, A.: "Análisis no lineal y comportamiento en servicio y rotura de secciones construidas evolutivamente sometidas a flexocompresión recta", Tesina de Especialidad (directores: Aguado de Cea, A.; Molins Borrell, C.). Barcelona, UPC, 2007.

(12) De la Fuente, A.; Aguado, A.; Molins, C.: "Modelo no lineal para el análisis de secciones prefabricadas construidas evolutivamente", Hormigón y Acero, 2008, vol. 57, 247, pp. 69-87.

(13) Revuelta, D.; Barona, A.; Navarro, D.: "Measurement of properties and of the resistance to segregation in heavyweight, selfcompacting barite concrete", Mater. Construcc., 2009, vol. 59, 295, pp. 31-44. doi:10.3989/mc.2009.43907

(14) Domone, P. L.: "Self-compacting concrete: an analysis of 11 years of case studies, S.L.", Cement and Concrete Composites, 28, 2006, pp. 197-2008. doi:10.1016/j.cemconcomp.2005.10.003

(15) AENOR, Asociación Española de Normalización y Certificación. UNE-EN 12350-6, Ensayos de hormigón fresco. Parte 6: Determinación de la densidad. Madrid, s.n., 2006. 
(16) UNE 83361 - Hormigón autocompactante - Caracterización de la fluidez - Ensayo del escurrimiento, Madrid, s.n., 2007.

(17) UNE 83362 - Hormigón autocompactante - Caracterización de la fluidez en presencia de barras - Ensayo del escurrimiento con el anillo japonés, Madrid, s.n., 2007.

(18) UNE-EN 12350-2 - Ensayos de hormigón fresco. Parte 2: Determinación del contenido de aire del hormigón fresco. Métodos de presión, Madrid, s.n., 2006.

(19) UNE-EN 12390-7 - Ensayos de hormigón endurecido. Parte 7: densidad del hormigón endurecido, Madrid, s.n., 2001.

(20) UNE-EN 12390-3 - Ensayos de hormigón endurecido. Parte 3: Determinación de la resistencia a compresión de probetas, Madrid, s.n., 2003.

(21) UNE 83515 - Hormigones con fibras. Determinación de la resistencia a fisuración, tenacidad y resistencia residual a tracción. Ensayo Barcelona, Madrid, s.n., 2008.

(22) Molins, C.; Aguado A.; Saludes S.: "Double Punch Test to control the tensile properties of FRC (Barcelona test)", Rev. Materials and Structures (RILEM), vol. 42, n 4, mayo de 2009, pp. 415-425.

(23) Turmo, J.; Banthia, N.; Gettu, R.; Barragán, B.: "Study of the shear behaviour of fibre reinforced concrete beams", Mater. Construcc., vol. 58, 292, 2008, pp. 5-13.

(24) Comisión Permanente del Hormigón. Instrucción del hormigón estructural EHE-08, Ministerio de Fomento, diciembre de 2008. 